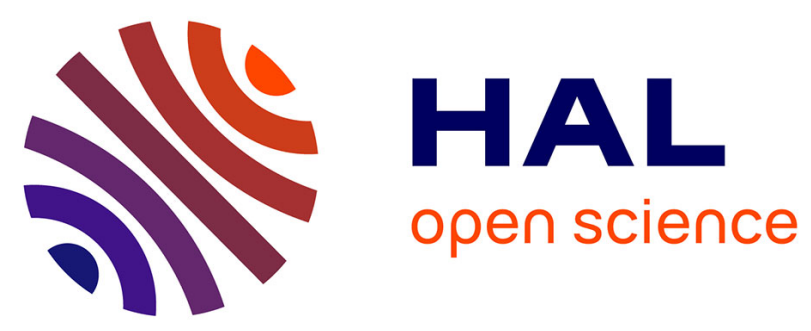

\title{
Targeted deletion of liver glucose- 6 phosphatase mimics glycogen storage disease type 1a including development of multiple adenomas.
}

Elodie Mutel, Aya Abdul-Wahed, Nirilanto Ramamonjisoa, Anne Stefanutti, Isabelle Houberdon, Sophie Cavassila, Frank Pilleul, Olivier Beuf, Amandine Gautier-Stein, Armelle Penhoat, et al.

\section{To cite this version:}

Elodie Mutel, Aya Abdul-Wahed, Nirilanto Ramamonjisoa, Anne Stefanutti, Isabelle Houberdon, et al.. Targeted deletion of liver glucose- 6 phosphatase mimics glycogen storage disease type 1a including development of multiple adenomas.. Journal of Hepatology, 2011, 54 (3), pp.529-37. 10.1016/j.jhep.2010.08.014 . hal-00575314

\section{HAL Id: hal-00575314 \\ https://hal.science/hal-00575314}

Submitted on 15 Mar 2011

HAL is a multi-disciplinary open access archive for the deposit and dissemination of scientific research documents, whether they are published or not. The documents may come from teaching and research institutions in France or abroad, or from public or private research centers.
L'archive ouverte pluridisciplinaire HAL, est destinée au dépôt et à la diffusion de documents scientifiques de niveau recherche, publiés ou non, émanant des établissements d'enseignement et de recherche français ou étrangers, des laboratoires publics ou privés. 
Targeted deletion of liver glucose- 6 phosphatase mimics glycogen storage disease type 1a including development of multiple adenomas

Elodie Mutel ${ }^{1-3}$, Aya Abdul-Wahed ${ }^{1-3}$, Nirilanto Ramamonjisoa N. ${ }^{2-4}$, Anne Stefanutti ${ }^{1-3}$, Isabelle Houberdon ${ }^{1-3}$, Sophie Cavassila ${ }^{2-4}$, Frank Pilleul ${ }^{2-4}$, Olivier Beuf ${ }^{2-4}$, Amandine Gautier-Stein $^{1-3}$, Armelle Penhoat ${ }^{1-3}$, Gilles Mithieux ${ }^{1-3}$ \& Fabienne Rajas ${ }^{1-3}$

${ }^{1}$ Institut National de la Santé et de la Recherche Médicale, U855, Lyon, F-69008, France ${ }^{2}$ Université de Lyon, Lyon, F-69008 France

${ }^{3}$ Université Lyon1, Villeurbanne, F-69622 France

${ }^{4}$ Creatis-LRMN ; CNRS UMR 5220; Inserm U630; INSA-Lyon ; Villeurbanne, F-69622

France

Address for correspondence: Dr. Fabienne Rajas

Faculté de Médecine Laennec

7 rue Guillaume Paradin

69372 Lyon cedex 08 France

Tel: 334787710 28/Fax: 33478778762

E-mail: fabienne.rajas@univ-lyon1.fr

Running title: Liver glycogen storage disease 1a mouse model

Electronic word count: 5450

Number of figures and tables: 6 Figures and 1 Table

Abbreviations used: Glucose-6 phosphatase (G6Pase), Catalytic subunit of G6Pase (G6PC), Glycogen storage disease type 1a (GSD1a), wild type (wt), Non esterified fatty acid (NEFA), Hepatocellular adenomas (HCA), magnetic resonance imagery (MRI)

Conflict of interest: The authors have declared that no conflict of interest exists. 


\section{ABSTRACT}

Background \& aims: Glycogen storage disease type 1a (GSD1a) is an inherited disease caused by a deficiency in the catalytic subunit of the glucose- 6 phosphatase enzyme (G6Pase). GSD1a is characterized by hypoglycaemia, hyperlipidemia, lactic acidosis, with associated hepatic (including hepatocellular adenomas), renal, and intestinal disorders. A total G6pc (catalytic subunit of G6Pase) knock-out mouse model has been generated that mimics the human pathology. However, these mice rarely live longer than 3 months and long-term liver pathogenesis cannot be evaluated. Here, we report the long-term characterization of a liver-specific G6pc knock-out mouse model $\left(L-G 6 p c^{-1 /}\right)$. Methods: We generated L-G6pc- mice using an inducible CRE-lox strategy and followed up the development of hepatic tumours using magnetic resonance imaging. Results: L-G6pc ${ }^{-1-}$ mice are viable and exhibit normoglycaemia in the fed state. They develop hyperlipidemia, lactic acidosis and uricemia during the first month after gene deletion. However, these plasmatic parameters improved after 6 months. L-G6pc- mice develop hepatomegaly with glycogen accumulation and hepatic steatosis. Using a MRI approach, we could detect hepatic nodules with diameters of less than $1 \mathrm{~mm}$, from 9 months after induction of deficiency. Hepatic nodules $(1 \mathrm{~mm})$ were detected in $30-40 \%$ of $\mathrm{L}-\mathrm{G} 6 \mathrm{pc} \mathrm{c}^{-/-}$mice at 12 months. After 18 months, all L-G6pc-/- mice developed multiple hepatocellular adenomas of 1 to $5 \mathrm{~mm}$ diameter. Conclusion: This is the first report of a viable animal model of the hepatic pathology of GSD1a, including the late development of hepatocellular adenomas.

Key words: glycogen storage disease, glucose-6 phosphatase, endogenous glucose production, hepatic steatosis, hepatic adenomas 


\section{Introduction}

Glycogen storage disease type I (GSD1) is a metabolic disorder characterized by severe hypoglycaemia associated with hepatic, renal and intestinal disorders [1]. This inborn disease is due to a deficiency in glucose-6 phosphatase (G6Pase) activity. G6Pase is an essential enzyme of endogenous glucose production. Patients affected with GSD1 are therefore unable to maintain blood glucose concentration outside the time of meals and suffer from severe hypoglycaemic episodes if they are not managed by continuous feeding [2-4]. GSD type 1a and type 1b respectively correspond to inherited mutations in the genes that encode the catalytic subunit (G6PC) and the transporter unit (G6PT) of the G6Pase system [1, 2, 5, 6]. The G6pc gene is expressed in the liver, kidney, and intestine, and these are the only organs that release glucose into the blood circulation [7-10]. G6Pase deficiency leads to accumulation of glucose-6 phosphate (G6P), glycogen, and triglycerides in the liver and kidneys of patients. This results in marked hepatomegaly and nephromegaly. In the liver, the long term complications of G6Pase deficiency include focal nodular hyperplasia and more often hepatocellular adenomas (HCA) with risk of malignant transformation [11, 12]. These tumours are often bleeding, multiple and non-encapsulated. The current treatments to prevent hypoglycaemia are based on nocturnal nutrition [13]. When HCA or liver failure occur, the management strategies are resection of the tumour and/or liver transplantation $[14,15]$.

To gain further insights into the long-term mechanisms of the disease and to evaluate potential treatment strategies, an animal model with sufficient life expectancy is required. Identification of the G6pc gene in 1993 has enabled a G6pc-knockout mouse model to be developed [16,17], as well as the evaluation of gene therapy approaches to correct G6pc deficiency ([18, 19], see [20] for review). However, long-term complications cannot be evaluated because even with continuous glucose therapy, the total G6pc knock-out mice rarely live to be over 3 months of age [16]. To investigate the long-term biology and 
pathogenesis of GSD-1a, we generated liver-specific $G 6 \mathrm{pc}^{-/-}$mice by an inducible CRE $\left(\mathrm{CRE}^{\mathrm{ERT2}}\right)$ strategy. We give a detailed characterization of this novel GSD1a mouse model over 18 months following inactivation of the G6pc gene in the liver. 


\section{MATERIALS AND METHODS}

\section{Generation of B6.g6pc ${ }^{\text {lox }}$ mice}

The targeting vector used for the homologous recombination strategy is shown in Figure $1 \mathrm{~A}$ and contained a $4.5 \mathrm{~kb} 5^{\prime}$ homologous $g 6 p c$ arm, a $3 \mathrm{~kb} 3$ ' homologous $g 6 p c$ arm and a neomycin resistance $\left(\mathrm{Neo}^{\mathrm{R}}\right)$ cassette. Two loxP sites flank G6pc exon 3 and two Frt sites flank $\mathrm{Neo}^{\mathrm{R}}$. We electroporated 129S2/SvPas mouse embryonic stem (ES) cells with the linearized construct. After selection, targeted clones were identified by PCR with external primers, with confirmation by Southern blotting with 5' and 3' external probes. Two positive ES clones were injected into C57BL/6J blastocysts. The male chimeras were mated with transgenic females expressing Flp recombinase to delete the $\mathrm{NeO}^{\mathrm{R}}$ cassette. Then, the $\mathrm{B} 6 ; \mathrm{g} 6 \mathrm{pc}^{\mathrm{lox} / \mathrm{w}}$ mice were backcrossed with the C57BI/6J strain for 10 generations (Charles Rivers Laboratories).

\section{Generation of liver-specific G6pc-null mice}

The $B 6.96 \mathrm{pc}^{\text {lox/w }}$ mice were crossed with transgenic mice expressing the inducible $\mathrm{CRE}^{\mathrm{ERT} 2}$ recombinase under the control of the serum albumin promoter to confer its liverspecific expression (B6. SA ${ }^{\text {creERT2/w) }}$ [21]. B6. SA ${ }^{\text {creERT2/w }}$ mice expressed, only in the liver, a recombinant Cre recombinase fused to a mutated ligand-binding domain of the estrogen receptor resulting in a tamoxifen-dependent Cre-recombinase [22, 23]. To induce the excision of G6pc exon 3, male adult (6 to 8 weeks old) B6.g6pc ${ }^{\text {lox/lox }} . S^{\text {creeRT2/w }}$ and B6.g6 $\mathrm{pc}^{\text {lox/w }} . S A^{\text {creeRT2/w }}$ mice were injected intraperitoneally once daily with $100 \mu$ of tamoxifen (10 mg/ml, Sigma-Aldrich) on five consecutive days, to obtain L-g6pc ${ }^{-/-}$and $\mathrm{L}$ $\mathrm{g}_{6 \mathrm{pc}^{+/}}$mice, respectively. Control C57BI/6J mice were treated with similar tamoxifen injections. All mice were housed in the animal facility of Lyon 1 University (Animaleries Lyon Est Conventionnelle et SPF in controlled temperature $\left(22^{\circ} \mathrm{C}\right)$ conditions, with a 12hour light-12-hour dark cycle. Mice had free access to water and standard rodent chow 
(Safe). Fasted mice were provided with continual free access to water. All procedures

were performed in accordance with the principles and guidelines established by the European Convention for the Protection of Laboratory Animals. The regional animal care committee (CREEA, CNRS, Rhône-Alpes Auvergne, France) approved all experiments. Mouse genotypes were determined from genomic DNA by PCR, with specific primers (Table 1, see Figure 1). Genomic DNA was extracted from tissues in PCR Direct Lysis buffer (Euromedex).

\section{Magnetic resonance imaging}

As previously described [24, 25], we performed MRI scans on mice anesthetized by isoflurane inhalation. This was done using a horizontal Biospec-7T Bruker system (Bruker, Ettlingen, Germany) with a cylindrical volumetric coil of $32 \mathrm{~mm}$ internal diameter (Rapid Biomedical, Würzburg, Germany). The body temperature of the mice was maintained at $37^{\circ} \mathrm{C}$ by warm water circulation. A pressure sensor was placed on the abdomen to monitor the respiratory cycle and to synchronize image acquisition with respiratory motion using a Trigger Unit HR V2.0 (Rapid Biomedical, Würzburg, Germany). Scout scans were performed to identify regions of interest and the graphical prescriptions for the following scan. Then, T2-weighted contrast images were acquired and analyzed in the axial plane based on a fat suppressed (FS) rapid acquisition with relaxation enhanced (RARE) sequence with the following parameters: echo time (TE) $40.4 \mathrm{~ms}$, field of view (FOV) $30 \times 30 \mathrm{~mm}^{2}$, matrix $256 \times 192,36$ or 48 slices, slice thickness $0.5 \mathrm{~mm}$, RARE factor $=8$. As previously described [24], the sequence was synchronized with respiration using balanced acquisitions over several respiratory periods with an effective repetition time (TR) of about $6 \mathrm{sec}$. Reading of MR images to detect adenomas was performed by a trained radiologist who had over fifteen years of experience. 


\section{Metabolic studies}

Blood was withdrawn from the tail vein and collected into EDTA or sodium fluorure/oxalate (anticoagulant). Plasma glucose, triglycerides, total cholesterol, uric acid and lactate concentrations were determined with Biomérieux colorimetric kits. Glucose-6 phosphate and glycogen determinations were carried out on frozen tissue homogenates as previously described [26, 27].

\section{Gene expression analysis}

Mice were killed by cervical dislocation $6 \mathrm{~h}$ after food removal. The frozen tissues were sampled, and G6Pase and PEPCK activities determined as previously described [10, 2830]. Immunoblotting was carried out using purified anti-rat G6PC (use at 1:1,500) or antiPEPCK (use at 1:5,000; Santa Cruz Biotechnology) antibodies [31]. Total RNAs were isolated from tissues with TRIzol reagent (Invitrogen). Reverse transcription and real-time PCR were performed as previously described [32], using sequence-specific primers (Table 1). The mouse ribosomal protein $\mathrm{mL} 19$ transcript $(R p / 19)$ was used as a reference.

\section{Histological analysis}

Tissues were fixed with 10\% formalin and embedded in paraffin. Cross-sections $(5 \mu \mathrm{m}$ thick) were cut and stained with hematoxylin and eosin (H\&E), periodic Acid Schiff (PAS) and picrosirius red staining. The slides were examined on a Coolscope microscope (Nikon, Tokyo, Japan).

\section{Statistical analyses}

Results are reported as means \pm SEM. The various groups were compared by MannWhitney tests. Differences were considered statistically significant if $P<0.05$. 


\section{RESULTS}

\section{Generation of a time-dependent and liver-specific deficiency of G6Pase in mice}

We disrupted G6Pase activity in the liver, by time dependent (conditional) and tissuespecific invalidation of the G6pc gene, based on a CRE-lox strategy. As endogenous glucose production, especially from the liver, is critical during the neonatal period (because of the low content of glucose in milk) [33,34], we have induced gene deletion in adult mice.

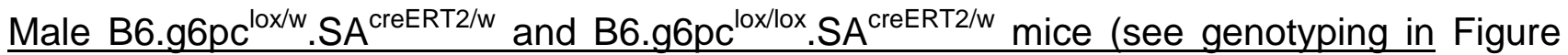
1B) were therefore treated with tamoxifen at 7-8 weeks of age. This resulted in the specific excision of exon 3 from both G6pc alleles, in the liver (Figure 1C). The liver-specific deletion of exon 3 in G6pc was confirmed at the mRNA level by RT-PCR on mRNA from the liver, kidney, and intestine of L-G6pc-/- and L-G6pc ${ }^{+-}$mice. Truncated G6pc mRNA was only amplified in the liver from L-G6pc $c^{-/-}$and L-G6pc ${ }^{+/}$mice (Figure 1D). Hepatic G6Pase activity was undetectable after one month of gene deletion $(0.31 \pm 0.13 \mathrm{U} / \mathrm{g}$ of protein in $\mathrm{L}$ G6pc ${ }^{-/}$versus $68.0 \pm 2.1 \mathrm{U} / \mathrm{g}$ of protein in control mice) (Figure 2A). Liver G6Pase activity remained undetectable in L-G6pc-/- mice $\left(0.30 \pm 0.08 \mathrm{U} / \mathrm{g}\right.$ of protein in L-g6pc $\left.{ }^{-/}\right)$after 18 months, confirming the persistence of the G6pc inactivation. Western blot analyses confirmed the absence of the G6PC protein from the livers of L-G6pc ${ }^{-/-}$mice (Figure 2A). In heterozygous mice $\left(\mathrm{L}-\mathrm{G} 6 \mathrm{p} \mathrm{c}^{+-}\right)$, G6Pase activity was only half of that in control mice $\left(39.2 \pm 2.9 \mathrm{U} / \mathrm{g}\right.$ of protein in $\left.\mathrm{L}-\mathrm{g} 6 \mathrm{pc}^{+/}\right)$and was correlated with the amount of G6PC protein detected on western blots (Figure 2A). Transcription of truncated G6pc mRNA appeared to be up regulated, with three times more G6pc mRNA in the liver of L-G6pc- mice than in controls (Figure 2B). This implies that there is a compensatory increase in gene expression in response to the absence of G6PC protein. The expression of cytosolic phosphoenolpyruvate carboxykinase (PEPCK-c, Pck1) was unaltered (Figures 2C and 2D). 
Expression of the genes encoding glucose-6-phosphate translocase (G6PT, S/c37a4) and

the transporter subunit of G6Pase remained unchanged (Figure 2E). Expression of the ubiquitous (non gluconeogenic) glucose-6-phosphatase-related protein (G6PC3 or UGRP) was also unaffected (Figure 2F).

\section{Metabolic effects of hepatic G6pc deficiency in mice}

The male and female L-G6pc ${ }^{-/}$mice showed similar survival rates to $\mathrm{C} 57 \mathrm{BI} / 6 \mathrm{~J}$ control (wt) and L-G6pc ${ }^{+/}$heterozygous mice (data not shown). However, in contrast to total G6pc ${ }^{-/-}$ mice, which are reported to have growth retardation [16], the loss of G6Pase specifically in the liver during adulthood had only marginal effect, if any, on weight gain (Figure 3A). Therefore, L-G6pc ${ }^{-/}$mice are fully viable and do not require glucose therapy to survive [16]. After some hours of fasting, the blood glucose concentration in L-G6pc-- mice could be lowered to about $3 \mathrm{mM}$ (data not shown). This is consistent with the crucial role of hepatic glycogenolysis in endogenous glucose production during the early post-absorptive state. However, in the fed state, mean blood glucose concentration in L-G6pc $c^{-/-}$mice was similar to L-G6pc ${ }^{-1+}$ and control mice (Figure 3B). The blood glucose concentrations of L$\mathrm{G}_{\mathrm{Npc}} \mathrm{c}^{-/+}$mice were similar to those of control mice (around $150 \mathrm{mg} / \mathrm{dL}$ ), even after $6 \mathrm{~h}$ of fasting (data not shown). This is consistent with the absence of blood glucose problems and any pathological phenotype in heterozygous human patients [3].

Biochemical analyses revealed highly disturbed plasma parameters just after deletion of G6pc in the liver. After ten days, L-G6pc-/- mice had plasma triglyceride and uric acid concentrations that were three times as high as those in control mice as well as plasma cholesterol concentrations that were twice as high (Figures 3C-E). L-G6pc/-- mice also had a plasma lactic acid concentration that had increased by $50 \%$ compared with control mice (Figure 3F). These concentrations remained high one month after gene deletion, but they 
then normalized with time; all metabolic plasma parameters except for cholesterol were normalized after 18 months (Figures 3C-F).

\section{LG6pc-/- mice develop hepatomegaly and steatosis}

As in GSD-1a patients and total G6pc knock-out mice, loss of hepatic G6PC led to accumulation of hepatic glucose-6 phosphate (G6P), glycogen, and triglycerides, which resulted in hepatomegaly and steatosis (Figure 4). The livers of L-G6pc/- mice were enlarged and pale (Figure $4 \mathrm{~A}$ ) and accounted for about $8 \%$ of total body mass, versus only $4 \%$ in control mice (Figure 4C). The deposition of glycogen increased between 10 days and one month after deletion, to reach about $50 \mathrm{mg}$ of glycogen/g in L-G6pc-/ liver at 18 months (Figures $4 \mathrm{E}$ ). Accumulation of triglycerides in L-G6pc-/ livers also increased with time (Figure 4F). Histological observations of L-G6Ppc ${ }^{-/-}$livers confirmed marked steatosis, with large hepatocytes containing large lipid vacuoles, mainly in the periportal area (Figure 5FG). As a result, the portal space was small and distorted (Figure 5G). Marked glycogen accumulation was also observed by periodic acid-Schiff staining (Figure $5 \mathrm{H}$ ). Picrosirius red staining of the L-G6pc-/ livers did not reveal any areas of fibrosis (Figure 5I). In contrast with total G6pc knock-out [16], the kidneys and intestine in L-G6pc-/- mice did not accumulate any glycogen. After 18 months, the weight $\left(0.16 \pm 0.01 \mathrm{~g}\right.$ for $\mathrm{L}-\mathrm{G} 6 \mathrm{pc} \mathrm{c}^{-/}$versus $0.15 \pm 0.1 \mathrm{~g}$ for controls) and histological features of $\mathrm{L}-\mathrm{G} 6 \mathrm{pc} \mathrm{c}^{-/}$kidneys were also completely normal (Figure 5J).

\section{Late appearance of hepatocellular adenomas in L-G6pc ${ }^{-/-}$mice}

Because of the short lifespan of total $G 6 p c^{-/-}$mice in the absence of glucose or gene therapy treatment, there was no possibility of detecting HCA. However, in the present study, using MRI, we were able to evaluate the development of nodules in the liver of LG6pc-/- mice. MRI was performed every three months, from 3 to 18 months after gene deletion. In less than $15 \%$ ( 3 out of 26 ) of L-G6PC ${ }^{-/-}$livers, small lesions could be detected 
as early as 9 months (data not shown). In about 30\% (8 out of 26 ) of L-G6PC ${ }^{-/-}$mice, small

nodules in the liver of about $1 \mathrm{~mm}$ diameter were first detected after one year (Figure 6A). At $15-16$ months, $40-50 \%$ of $\mathrm{L}-\mathrm{G} 6 \mathrm{pc} \mathrm{c}^{-/-}$mice had liver nodules between 1 and $3 \mathrm{~mm}$ diameter. At 18 months, all $(\mathrm{n}=17) \mathrm{L}-\mathrm{G} 6 \mathrm{pc}^{-/-}$mice had developed liver nodules between 1 and $10 \mathrm{~mm}$ diameter (Figures $6 \mathrm{~B}$ and $\mathrm{C}$ ). There was at least one, and up to 5 large nodules $(>4-5 \mathrm{~mm})$ in each liver at this time (Figure $6 \mathrm{E}-\mathrm{F}$ ). Panels $6 \mathrm{~A}$ and $\mathrm{B}$ show the development of one nodule on $\mathrm{MRI}$ from 12 months $(6 \mathrm{~A})$ through to 18 months $(6 \mathrm{~B})$ following gene deletion. No obvious necrosis or significant haemorrhage was seen. The nodules were well demarcated from the surrounding liver, without a fibrous capsule (Figures $6 \mathrm{G}$ and $6 \mathrm{H}$ ). More than 20 biopsies of GSD1a livers ( $\mathrm{n}=17$ mice) were analyzed by immunohistochemistry (H\&S staining). No portal spaces were seen within the nodules. In most cases (80\%), the hepatocytes within the nodule were large and swollen, with pale cytoplasms (Figures $6 \mathrm{G}$ and $6 \mathrm{I}$ ). Areas of necrosis and inflammation were seen within the nodules (Figure 6l). The tumour shown in Figure 6G proved to be an adenoma. In a few cases (about 20\%), the hepatocytes within the nodules were small, suggesting the development of a "precarcinoma" lesion (Figures $6 \mathrm{H}$ and $\underline{6 \mathrm{~J}}$ ). Areas of necrosis and numerous foci of inflammation were also present within these nodules (data not shown). In no case, pericellular fibrosis was observed around hepatic nodules. Moreover, no atypia was noted in any of the nodules. No mice developed hepatocellular carcinoma in the course of this study. 


\section{DISCUSSION}

The maintenance of blood glucose levels within a narrow range (about $1 \mathrm{~g} / \mathrm{L}$ ) is a critical physiological function. Outside of the time of meals and during fasting, endogenous glucose production is wholly responsible for maintaining plasma glucose levels. Glucose can be produced only in the liver, kidney, and intestine, because these are the only organs known to express G6Pase, the key enzyme for endogenous glucose production (for review see [9]). Among these organs, the liver has a special role because it is able to rapidly mobilize glucose stored under the form of glycogen. Although the liver is the main glucoseproducing organ under post-absorptive conditions, we hypothesized that the inactivation of G6pc in the liver only would not be lethal, because of compensatory glucose production by the kidneys and intestine. This type of compensation has already been reported during the anhepatic phase of liver transplantation in humans [35], and has been suggested in mice with inactivation of $P c k 1$ in the liver [36]. In line with our hypothesis, L-G6pc $c^{-/-}$mice are normoglycemic in the fed state. This strongly suggests that glucose release by the kidney and intestine is sufficient to exquisitely regulate blood glucose concentration in L-G6pc ${ }^{-1-}$ mice when unrestrained food is available. Furthermore, L-G6pc ${ }^{-/-}$mice had a normal survival rate, which allowed us, for the first time, to evaluate the development of GSD1a pathology in the livers of the mice, up to 18 months of age.

As expected, the liver of L-G6pc-/ mice is rapidly enlarged, due to the accumulation of glucose-6 phosphate, glycogen, and triglycerides. In parallel, there is a rapid increase in plasma triglycerides, cholesterol, lactic, and uric acids, as also observed in human GSD1a patients and in total G6pc knock-out mice [3,4]. Together with the absence of kidney and gut deficiency and phenotype in L-G6pc ${ }^{-/}$mice, this strongly suggests that the liver deficiency may be fully responsible for the deregulation of plasma parameters in GSD1a. Whereas some liver parameters tended to worsen with time (e.g. liver TG content), others 
(blood parameters) progressively decreased towards control values (e.g. uricemia and

lactatemia). This suggests that there are some compensatory mechanisms taking place over time to correct the primary defaults initiated by the liver deficiency. Interestingly, a comparable improvement of blood biochemical profile was also observed after some months in the total G6pc knock-out mice surviving thanks to pre-weaning management with glucose injection and post-weaning management with Nutragel and glucose added to the drinking water [37]. However, as in LG6pc ${ }^{-1-}$ mice, liver histology and glycogen accumulation did not improve with aging [37]. Therefore, it is probable that a satisfying control of blood glucose could explain this amelioration (dependent either on exogenous supply or on compensation by extrahepatic endogenous sources). This is also in line with the observation that GSD1a pathology is better tolerated with patient aging, and that some of the metabolic plasma parameters have been reported to be at least partially corrected with time [3].

To detect the putative appearance of hepatic adenomas as soon as possible while preserving the living animal, we used MRI, a powerful imaging technique, which allowed us to identify hepatic nodules about $1 \mathrm{~mm}$ in diameter. The first nodules were detected at 9 months of age, and after 18 months all livers in L-G6pc/- mice showed at least one largesized lesion. As in human GSD1a, the adenomas were multiple, non-encapsulated, and in about $20 \%$ of cases, showed features of pre-carcinomas. It should be noted that adenomas were first detected at 9 months, a time when several plasma parameters had been normalized. However, this late detection cannot exclude that the development of adenomas may have started much earlier but they were not large enough to be detected by MRI. However, it is important to note that the development of adenoma appeared rather lately, whilst liver steatosis tended to worsen (see Figure 4). In the same time, several plasma parameters were markedly corrected, suggesting that the development of HCA was dependent on the alteration of liver metabolism and not on the deregulation of the 
plasma parameters. Moreover, intrahepatic metabolic disturbances induced by G6Pase

deficiency had the capacity to initiate adenoma formation in all of the livers studied. Furthermore, even if hepatocellular carcinoma was not observed, a substantial proportion of the adenomas could be prone to develop into carcinomas.

In conclusion, we report the characterization of a novel animal model of GSD1a, which is exclusively targeted to the liver. We demonstrate that L-G6Ppc-/- mice have all the hepatic symptoms of the human pathology, including hepatomegaly, steatosis, glycogen overload. L-G6pc- mice also have the expected dysregulations of plasma metabolites related to liver function such as triglycerides, cholesterol, lactic and uric acids. Our animal GSD1a model is perfectly viable without treatment and is normoglycaemic when food is available. Because of this, for the first time we are able to report that the development of adenomas is bound to happen with time in GSD1a livers. In addition, a significant proportion of these adenomas exhibit the features of pre-carcinomas. Because of its viability, this new animal model will be extremely useful for a better understanding of the pathological mechanisms of GSD1a. It will also be of value in assessing the effects of food quality on delaying the deleterious consequences of the disease (e.g. adenomas). Our model should be able to help refine the different gene therapy approaches aimed at correcting G6Pase expression in the liver. Finally, in the near future, the CRE-lox approach that was used to generate the liver-deficient model, will allow us to assess the consequences of kidney or intestine pathology. This will be based on the use of a CRE recombinase expressed under the control of adapted gut or kidney gene promoters to specifically target the deficiency to either organ. 


\section{ACKNOWLEDGMENTS}

We would like to thank the Mouse Clinical Institute (Strasbourg, France) for invaluable help in generating the $B 6 . g 6 \mathrm{pc}^{\mathrm{lox}}$ mice. This work received financial support from the "Association Française contre les Myopathies" (Paris, France) and the "GIS-Institut des Maladies Rares" (Paris, France). We also thank Prof. Pierre Chambon and Dr. Daniel Metzger (Mouse Clinical Institute, Strasbourg, France) for generously providing B6. $\mathrm{SA}^{\text {CreERT2 }}$ transgenic mice, Nicolas Gadot and Prof. Jean-Yves Scoazec (ANIPATH, Faculty of Medecine Laennec, Lyons, France) for carrying out the histology study, Angèle Chamousset and Jean-Michel Vicat for animal care (ALECS, Faculty of Medecine Laennec, IFR62 Lyon-Est, Lyons), Jean-Baptiste Langlois for MRI acquisitions (Animage Platform, Cermep, Lyons) and the members of the CECIL Platform (Faculty of Medecine Laennec, IFR62 Lyon-Est, Lyons). This work was supported by research grants from the "Agence Nationale de la Recherche" (ANR-07-MRAR-011-01) and the "Association Francophone des Glycogénoses". 


\section{REFERENCES}

[1] Chou JY, Mansfield BC. Mutations in the glucose-6-phosphatase-alpha (G6PC) gene that cause type la glycogen storage disease. Hum Mutat 2008;29:921-930.

[2] Chou JY, Matern D, Mansfield BC, Chen YT. Type I glycogen storage diseases: disorders of the glucose-6-phosphatase complex. Curr Mol Med 2002;2:121-143.

[3] Moses SW. Historical highlights and unsolved problems in glycogen storage disease type 1. Eur J Pediatr 2002;161 Suppl 1:S2-9.

[4] Ozen H. Glycogen storage diseases: new perspectives. World J Gastroenterol 2007;13:2541-2553.

[5] Bruni N, Rajas F, Montano S, Chevalier-Porst F, Maire I, Mithieux G. Enzymatic characterization of four new mutations in the glucose-6 phosphatase (G6PC) gene which cause glycogen storage disease type 1a. Ann Hum Genet 1999;63:141-146.

[6] Chevalier-Porst F, Bozon D, Bonardot AM, Bruni N, Mithieux G, Mathieu M, Maire I. Mutation analysis in 24 French patients with glycogen storage disease type 1a. J Med Genet 1996;33:358-360.

[7] Croset M, Rajas F, Zitoun C, Hurot JM, Montano S, Mithieux G. Rat small intestine is an insulin-sensitive gluconeogenic organ. Diabetes 2001;50:740-746.

[8] Mithieux G, Bady I, Gautier A, Croset M, Rajas F, Zitoun C. Induction of control genes in intestinal gluconeogenesis is sequential during fasting and maximal in diabetes. Am J Physiol Endocrinol Metab 2004;286:E370-375.

[9] Mithieux G, Rajas F, Gautier-Stein A. A novel role for glucose 6-phosphatase in the small intestine in the control of glucose homeostasis. J Biol Chem 2004;279:44231-44234. [10] Rajas F, Bruni N, Montano S, Zitoun C, Mithieux G. The glucose-6 phosphatase gene is expressed in human and rat small intestine: regulation of expression in fasted and diabetic rats. Gastroenterology 1999;117:132-139. 
[11] Cassiman D, Libbrecht L, Verslype C, Meersseman W, Troisi R, Zucman-Rossi J,

Van Vlierberghe $\mathrm{H}$. An adult male patient with multiple adenomas and a hepatocellular carcinoma: Mild Glycogen Storage Disease type la. J Hepatol 2010;53:213-217.

[12] Franco LM, Krishnamurthy V, Bali D, Weinstein DA, Arn P, Clary B, Boney A, et al. Hepatocellular carcinoma in glycogen storage disease type la: a case series. J Inherit Metab Dis 2005;28:153-162.

[13] Heller S, Worona L, Consuelo A. Nutritional therapy for glycogen storage diseases. J Pediatr Gastroenterol Nutr 2008;47 Suppl 1:S15-21.

[14] Labrune P, Trioche P, Duvaltier I, Chevalier P, Odievre M. Hepatocellular adenomas in glycogen storage disease type I and III: a series of 43 patients and review of the literature. J Pediatr Gastroenterol Nutr 1997;24:276-279.

[15] Matern D, Starzl TE, Arnaout W, Barnard J, Bynon JS, Dhawan A, Emond J, et al. Liver transplantation for glycogen storage disease types I, III, and IV. Eur J Pediatr 1999;158 Suppl 2:S43-48.

[16] Lei KJ, Chen H, Pan CJ, Ward JM, Mosinger B, Jr., Lee EJ, Westphal H, et al. Glucose-6-phosphatase dependent substrate transport in the glycogen storage disease type-1a mouse. Nat Genet 1996;13:203-209.

[17] Shelly LL, Lei KJ, Pan CJ, Sakata SF, Ruppert S, Schutz G, Chou JY. Isolation of the gene for murine glucose-6-phosphatase, the enzyme deficient in glycogen storage disease type 1A. J Biol Chem 1993;268:21482-21485.

[18] Ghosh A, Allamarvdasht M, Pan CJ, Sun MS, Mansfield BC, Byrne BJ, Chou JY. Long-term correction of murine glycogen storage disease type la by recombinant adenoassociated virus-1-mediated gene transfer. Gene Ther 2006;13:321-329.

[19] Yiu WH, Lee YM, Peng WT, Pan CJ, Mead PA, Mansfield BC, Chou JY. Complete Normalization of Hepatic G6PC Deficiency in Murine Glycogen Storage Disease Type la Using Gene Therapy. Mol Ther 2010; 18:1076-1084 
[20] Chou JY, Mansfield BC. Gene therapy for type I glycogen storage diseases. Curr

\section{Gene Ther 2007;7:79-88.}

[21] Schuler M, Dierich A, Chambon P, Metzger D. Efficient temporally controlled targeted somatic mutagenesis in hepatocytes of the mouse. Genesis 2004;39:167-172.

[22] Feil R, Brocard J, Mascrez B, LeMeur M, Metzger D, Chambon P. Ligand-activated site-specific recombination in mice. Proc Natl Acad Sci U S A 1996;93:10887-10890.

[23] Nagy A. Cre recombinase: the universal reagent for genome tailoring. Genesis 2000;26:99-109.

[24] Baboi L, Pilleul F, Milot L, Lartizien C, Poncet G, Roche C, Scoazec JY, et al. Magnetic resonance imaging follow-up of liver growth of neuroendocrine tumors in an experimental mouse model. Magn Reson Imaging 2010;28:264-272.

[25] Beuf O, Lartizien C, Milot L, Baboi L, Roche C, Langlois JB, Scoazec JY, et al. Multimodal imaging for the detection and characterization of liver lesions in a mouse model of neuroendocrine tumor. Gastroenterol Clin Biol 2008;32:32-40.

[26] Guignot L, Mithieux G. Mechanisms by which insulin, associated or not with glucose, may inhibit hepatic glucose production in the rat. Am J Physiol 1999;277:E984989.

[27] Mithieux G, Guignot L, Bordet JC, Wiernsperger N. Intrahepatic mechanisms underlying the effect of metformin in decreasing basal glucose production in rats fed a high-fat diet. Diabetes 2002;51:139-143.

[28] Daniele N, Rajas F, Payrastre B, Mauco G, Zitoun C, Mithieux G. Phosphatidylinositol 3-kinase translocates onto liver endoplasmic reticulum and may account for the inhibition of glucose-6-phosphatase during refeeding. $\mathrm{J}$ Biol Chem 1999;274:3597-3601. 
[29] Mithieux G, Daniele N, Payrastre B, Zitoun C. Liver microsomal glucose-6-

phosphatase is competitively inhibited by the lipid products of phosphatidylinositol 3kinase. J Biol Chem 1998;273:17-19.

[30] Rajas F, Croset M, Zitoun C, Montano S, Mithieux G. Induction of PEPCK gene expression in insulinopenia in rat small intestine. Diabetes 2000;49:1165-1168.

[31] Rajas F, Jourdan-Pineau H, Stefanutti A, Mrad EA, lynedjian PB, Mithieux G. Immunocytochemical localization of glucose 6-phosphatase and cytosolic phosphoenolpyruvate carboxykinase in gluconeogenic tissues reveals unsuspected metabolic zonation. Histochem Cell Biol 2007;127:555-565.

[32] Pillot B, Soty M, Gautier-Stein A, Zitoun C, Mithieux G. Protein feeding promotes redistribution of endogenous glucose production to the kidney and potentiates its suppression by insulin. Endocrinology 2009;150:616-624.

[33] Chatelain F, Pegorier JP, Minassian C, Bruni N, Tarpin S, Girard J, Mithieux G. Development and regulation of glucose-6-phosphatase gene expression in rat liver, intestine, and kidney: in vivo and in vitro studies in cultured fetal hepatocytes. Diabetes 1998;47:882-889.

[34] Girard J, Ferre P, Pegorier JP, Duee PH. Adaptations of glucose and fatty acid metabolism during perinatal period and suckling-weaning transition. Physiol Rev 1992;72:507-562.

[35] Battezzati A, Caumo A, Martino F, Sereni LP, Coppa J, Romito R, Ammatuna M, et al. Nonhepatic glucose production in humans. Am J Physiol Endocrinol Metab 2004;286:E129-135.

[36] She P, Burgess SC, Shiota M, Flakoll P, Donahue EP, Malloy CR, Sherry AD, et al. Mechanisms by which liver-specific PEPCK knockout mice preserve euglycemia during starvation. Diabetes 2003;52:1649-1654. 
[37] Salganik SV, Weinstein DA, Shupe TD, Salganik M, Pintilie DG, Petersen BE. A 1 detailed characterization of the adult mouse model of glycogen storage disease la. Lab 2 Invest 2009;89:1032-1042. 


\section{FIGURE LEGENDS}

Figure 1. Targeting strategy used to generate liver-specific g6pc null mice $\left(L-g 6 p c^{-/-}\right)$. (A) Scheme of the wild-type G6pc allele $\left(G 6 p c^{\mathrm{w}}\right)$, located on chromosome 11, and the targeting vector. Black rectangles represent exons and the 5' and 3' untranslated sequences are indicated by white rectangles. In the targeting vector map, LoxP sequences are represented as triangles and flags indicate frt sequences. $\mathrm{Neo}^{\mathrm{R}}$ : neomycin resistance gene cassette. Bold line segments: arms of homology. After homologous recombination between the G6pc ${ }^{\mathrm{w}}$ locus and the targeting vector in ES cells, $\mathrm{Neo}^{\mathrm{R}}$ was removed to obtain the $G 6 p c^{\text {lox }}$ allele through FLP recombination. Exon 3 of G6pc was specifically excised by CRE recombination (G6pc del). Specific primers (Table 1) for genotyping were identified ( $p 1$, p2 and p3). (B) PCR genotype analysis on the basis of tail DNA, using the p2 and p3 primers, which yielded products of 385 and 486 bp for the wild-type and floxed G6pc alleles, respectively. Specific primers were used to amplify a $320 \mathrm{bp}$ Cre fragment. The expected sizes are shown on the left of the panel. (C) PCR genotype analysis on the basis of tail and liver DNA, using p1 and p3 primers. Fragments of 1189, 1029 and 595 bp correspond to the $G 6 p c{ }^{10 x}, G 6 p c{ }^{\text {w }}$ and G6pc del alleles, respectively. (D) Liver-specific excision of G6pc exon 3. RT-PCR analysis on liver, kidney or intestine mRNA, from L-g6pc /-, L-g6pc ${ }^{+/-}$and L-g6pc ${ }^{+/+}$(C57BI/6J) mice, using G6pc exon 2 and exon 5 primers. A 761 bp DNA fragment is obtained from the wt allele and the deletion of exon 3 yields a $655 \mathrm{bp}$ DNA fragment. Comparable data were obtained at 10 days or 18 months after tamoxifen treatment.

Figure 2. Glucose-6-phosphatase is absent in the liver of liver-specific G6pc-null mice (L-G6pc ${ }^{-1 /}$ ). (A and C) G6Pase and PEPCK-C activities were assayed in the liver of 
homozygous L-G6pc-- (black bar), heterozygous L-G6pc ${ }^{+-}$(grey bar) and wt (white bar)

mice. Top of panels, western-blot analyses of liver tissues for G6PC and PEPCK-c proteins. (B, D, E and F) G6pc, Pck1, G6pt (Slc37a4) and G6pc3 mRNA levels were determined by RT-qPCR in the livers of L-G6pc (black bar), L-G6pc $c^{+/-}$(grey bar) and wt (white bar) mice. The results are expressed as a ratio relative to $R p / 19$ expression. Data were obtained five weeks after tamoxifen injections from mice fasting for $6 \mathrm{~h}$ and are expressed as means \pm SEM ( $n=6$ mice per group). Values which are significantly different from wt $\left(P<0.05^{\star}, P<0.01^{* *}\right)$ are indicated.

Figure 3. Body weight and plasmatic parameters of L-G6pc/-- mice. (A) Growth rates of L-G6pc ${ }^{-1}$ (black symbols) and wt (white symbols) male and female mice. Body weight was followed once a month after gene deletion. Blood glucose (B), triglycerides (C), total cholesterol (D), uric acid (E) and lactic acid (F) were analysed at 10 days, 1 month, 6 months and 18 months after gene deletion in L-G6pc ${ }^{-/-}$(black bars) and control L-G6pc ${ }^{+/+}$ (white bars) mice upon $6 \mathrm{~h}$ of fasting, except for glucose, which was determined in the fed state. The results are expressed as mean $\pm \operatorname{SEM}(n=6$ to 8 per group). Values significantly different from wt $\left(\mathrm{P}<0.05^{\star}\right.$ and $\left.\mathrm{P}<0.01^{\star *}\right)$ are indicated.

Figure 4. Liver-specific G6pc null mice develop liver hepatomegaly and steatosis. (A) Livers of L-G6pc-/- and wt mice. (B) Liver weight, (C) Liver weight compared to the body weight, (D) Liver glucose-6 phosphate content, (E) Liver glycogen content (F) Liver triglyceride content of L-G6pc ${ }^{-/-}$(black bar) and wt (white bar) mice. Data were obtained 10 days, 1 month and 18 months after tamoxifen injections, from mice fasted for $6 \mathrm{~h}$ and are expressed as means \pm SEM ( $n=6$ mice per group). Values which significantly different from wt $\left(\mathrm{P}<0.05^{\star}, \mathrm{P}<0.01^{\star *}\right)$ are indicated.

Figure 5. Histology and glycogen storage analyses of the liver and the kidneys of 
L-G6pc ${ }^{-/-}$and control mice, one month after tamoxifen treatment. H\&E stained sections from control liver (A-B) and kidneys (E) and from L-G6pc- livers (F-G) and kidneys (J). PAS-stained liver from control $(\mathbf{C})$ and from $L-G 6 p c^{-/-}(\mathbf{H})$ mice. Picrosirius red staining of control (D) and from L-G6pc (I) mice.

Figure 6. Development of liver nodules in L-G6pc-/- mice after one year of gene deletion. T2-weighted axial MR images showing the evolution of liver lesions at 12 months (A) and 18 months (B-C) after G6pc deletion. Liver resection after 18 months of tamoxifen treatment in control mice (D) or in L-G6pc/-- mice (E-F) with multiple tumour nodules. Histological analysis of two different tumours from L-G6pc-/ liver stained with H\&S (G-J). Panel I corresponds to a higher magnification of the adenoma showed on panel $G$ and panel $\mathrm{J}$ corresponds to the tumour of panel $\mathrm{H}$. Arrows in panels $\mathrm{H}$ and $\mathrm{J}$ point the edge of the tumour, revealing the absence of fibrous encapsulation. 


\section{Table 1}

Oligodeoxyribonucleotide primer sequences for PCR (top) and qPCR (bottom). $S=$ sense and $\mathrm{AS}=$ antisense sequences.

\begin{tabular}{ll}
\hline \multicolumn{1}{c}{ Name } & \multicolumn{1}{c}{ Sequence } \\
\hline p1S & 5'-AGGGAGTTGACCAGAGGAACTTTGG-3' \\
p2S & 5'-GCTCATTCTCACACCTACAGTTGG-3' \\
p3AS & 5'-TGTTCCTAACTACTGAGCCATTGCTCC-3' \\
CreS & 5'- TTCCCGCAGAACCTGAAGATGTTCG-3' \\
CreAS & 5'-GGGTGTTATAAGCAATCCCCAGAAATGC-3' \\
Exon 2 mG6pc S & 5'-TCCCTGTCACCTGTGAG-3' \\
Exon 5 mG6pc AS & 5'-CACAAGAAGTCTTTGTAA-3' \\
\hline \hline Exon1 mG6pcS & 5'-TTACCAAGACTCCCAGGACTG-3' \\
Exon2 mG6pcAS & 5'-GAGCTGTTGCTGTAGTAGTCG-3' \\
mL19S & 5'-AGAAGATTGACCGCCATAT-3' \\
mL19AS & 5'-TTCGTGCTTCCTTGGTCTTAGA-3' \\
G6pc3S & 5'-GCACATTTCCCTCACCAAGT-3' \\
G6pc3AS & 5'-GGTTGATGGACCAGGAAAGA-3' \\
G6ptS & 5'-TGGTTGGTCTGGTCAACGTA-3' \\
G6ptAS & 5'-TGCCAAGATAGGTCCCAAAC-3' \\
Pck1S & 5'-AGCCTTTGGTCAACAACTGG-3' \\
Pck1AS & 5'-TGCCTTCGGGGTTAGTTATG-3' \\
\hline
\end{tabular}


A

Ch. 11

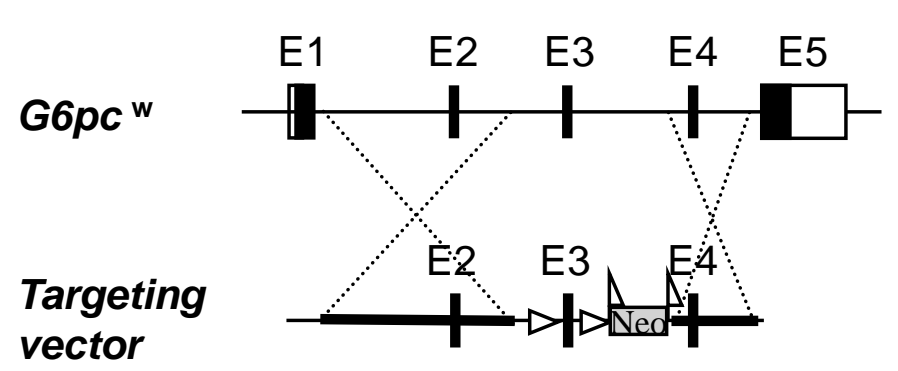

G6pclox+neo

G6pc lox

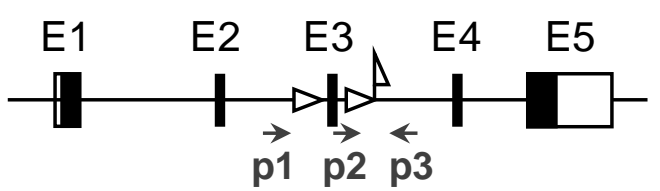

G6pc del

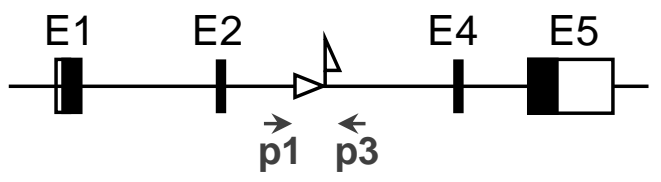

B

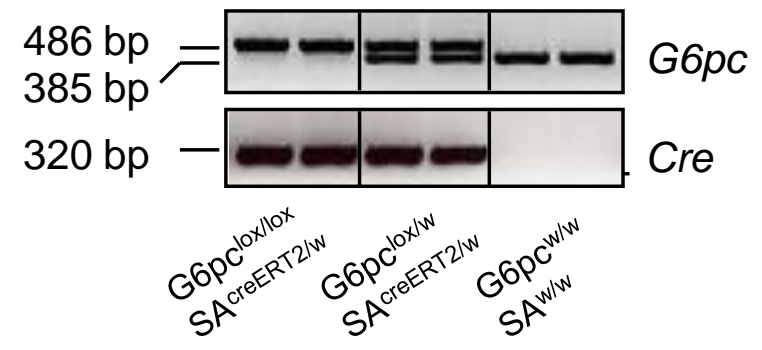

C

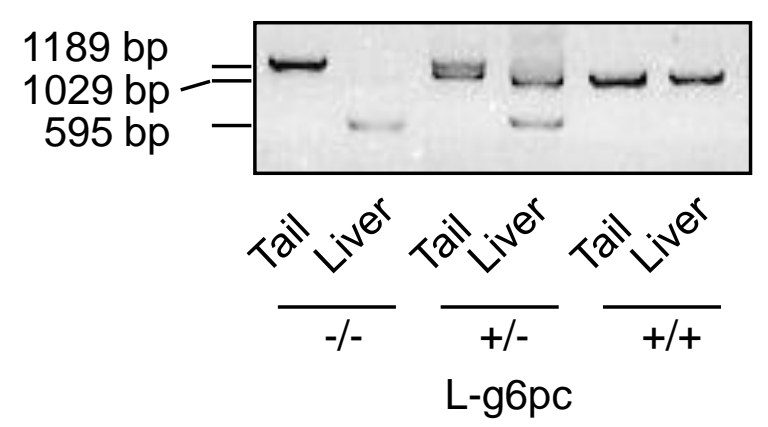

D

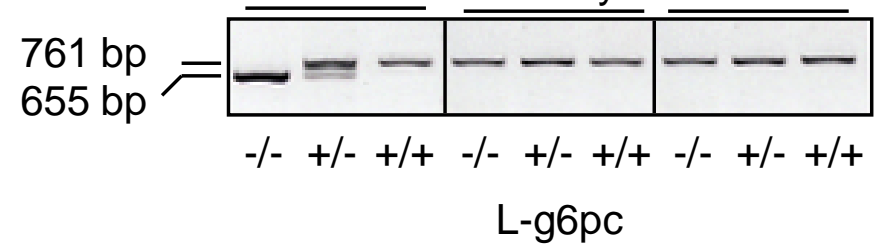

Mutel et al., Figure 1 
A

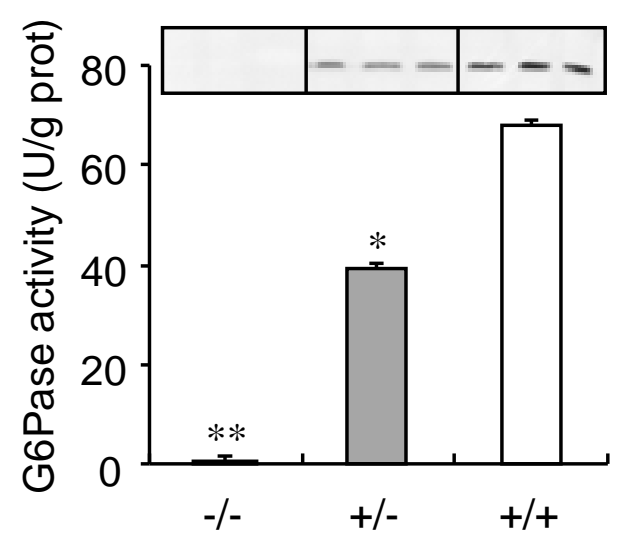

C

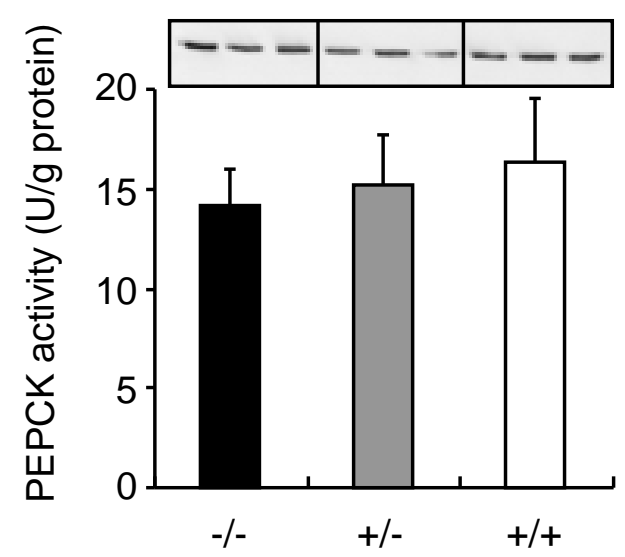

E

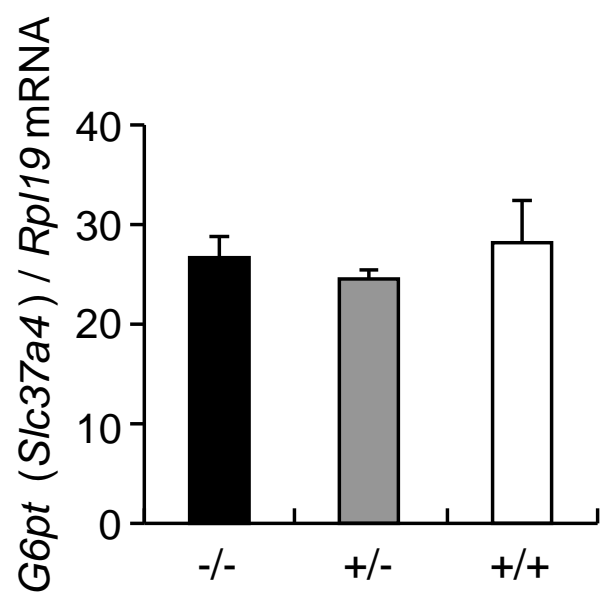

B

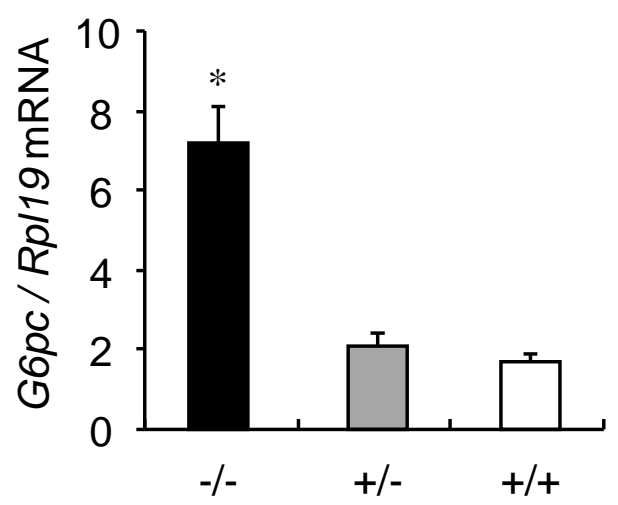

D

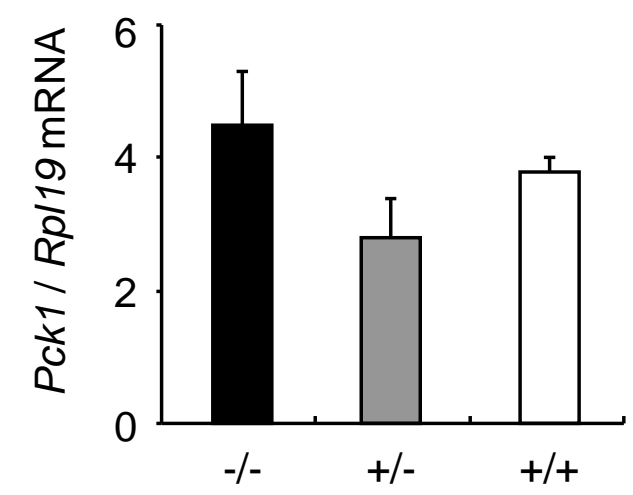

F

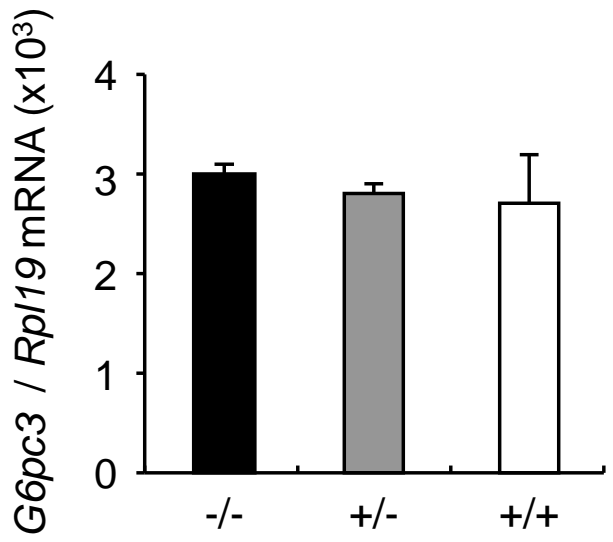


A

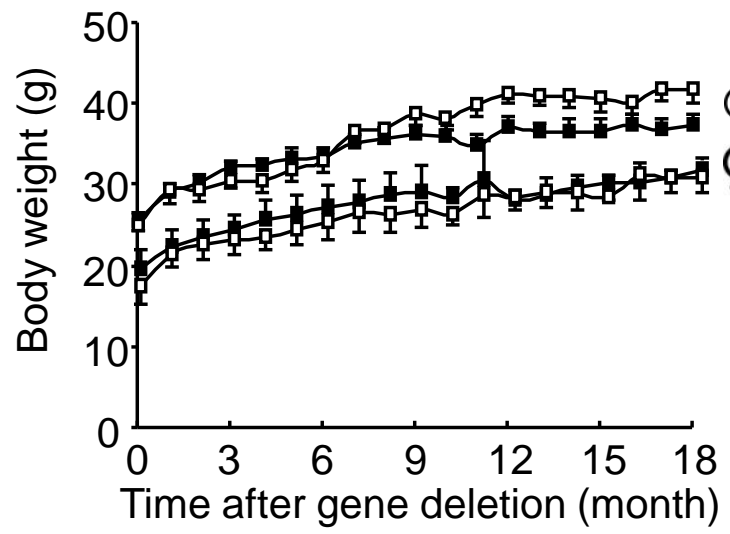

C

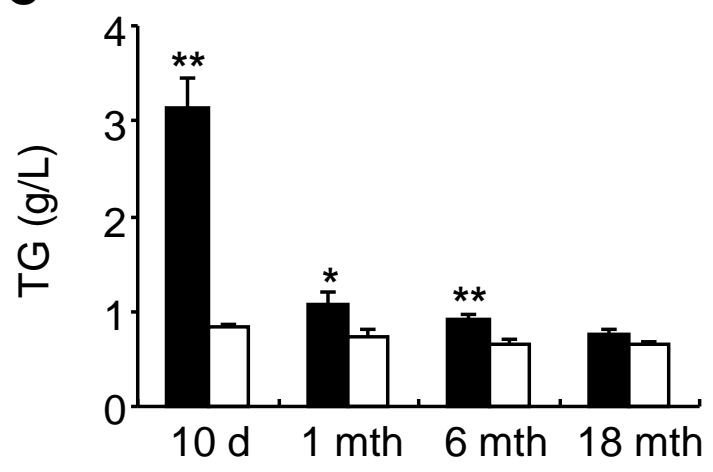

E

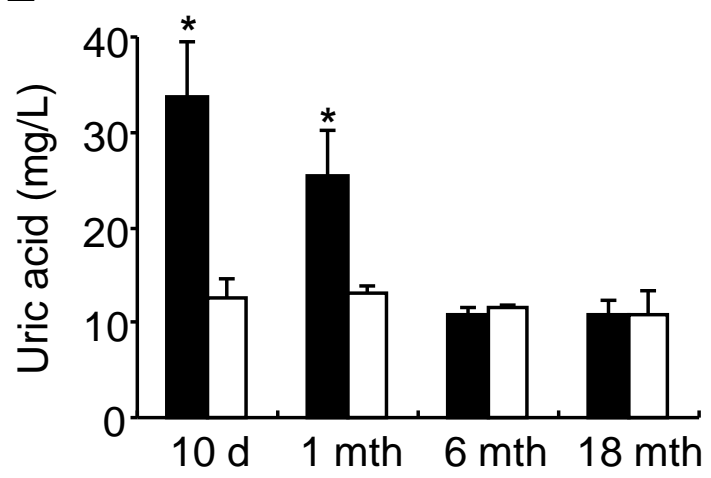

B

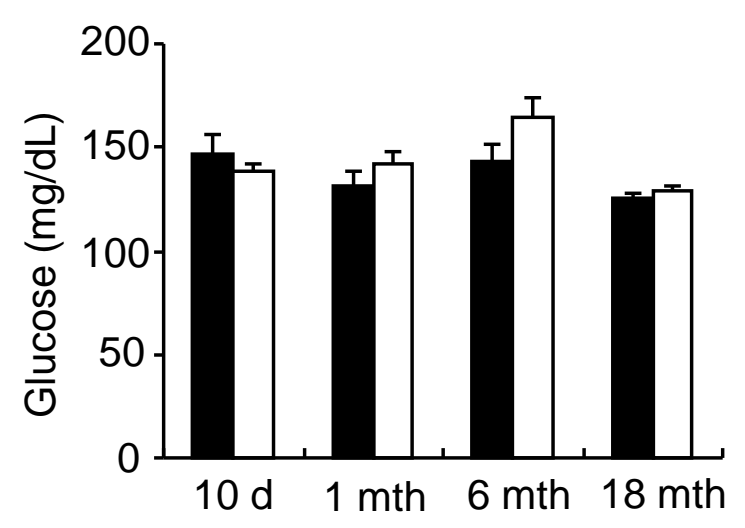

D

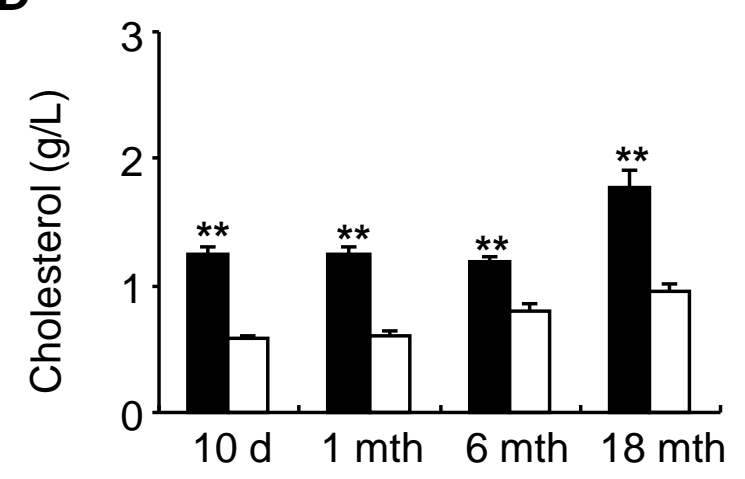

$\mathbf{F}$

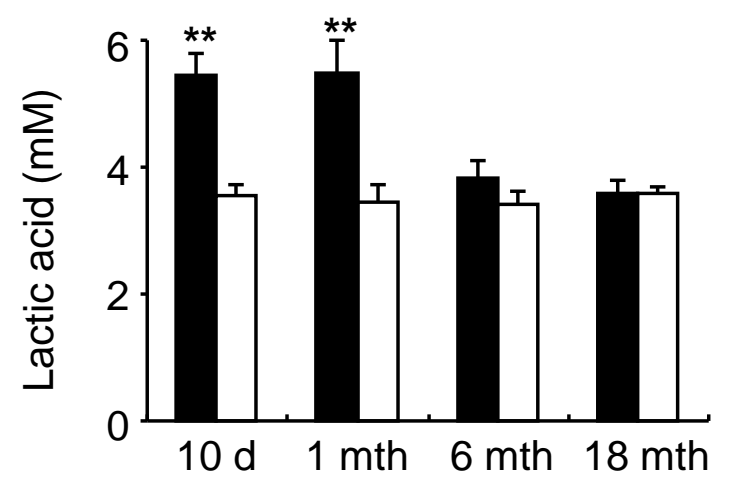


A

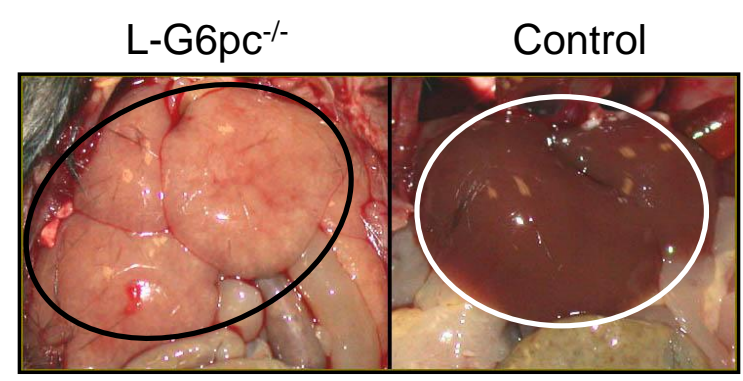

B

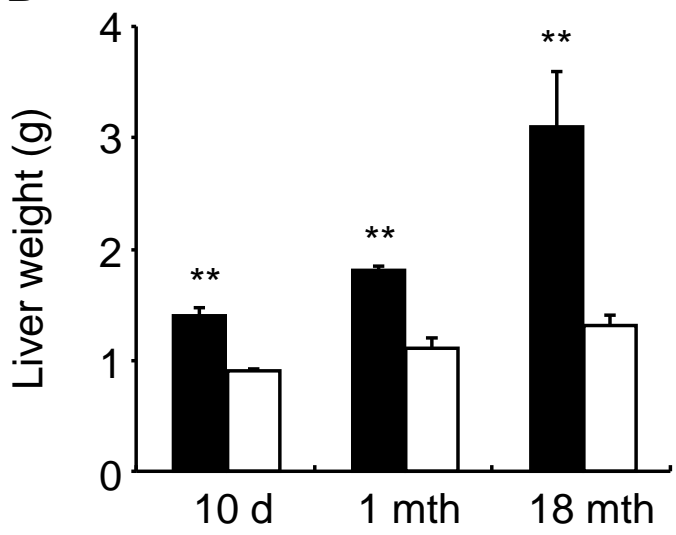

C

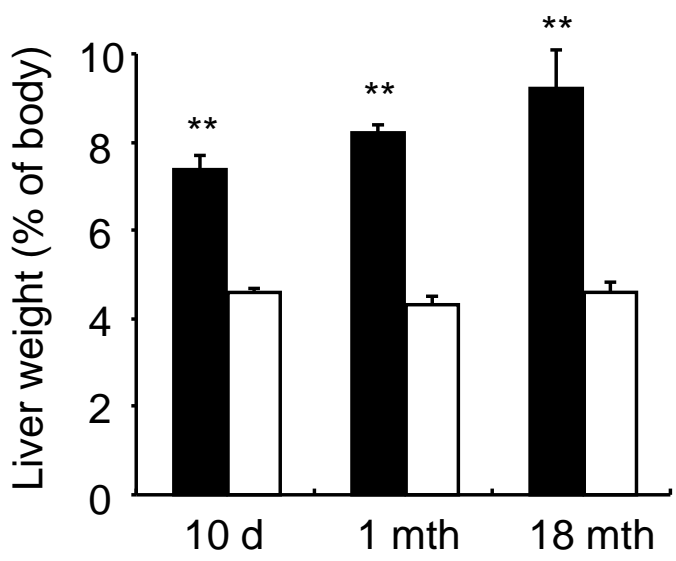

D

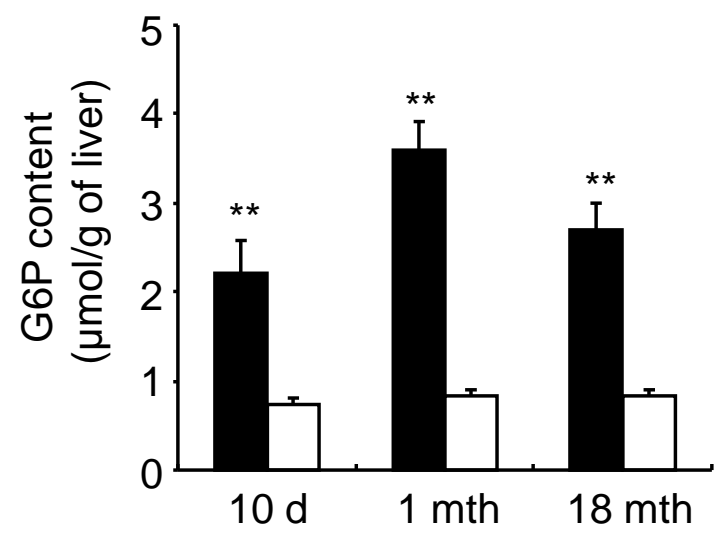

E

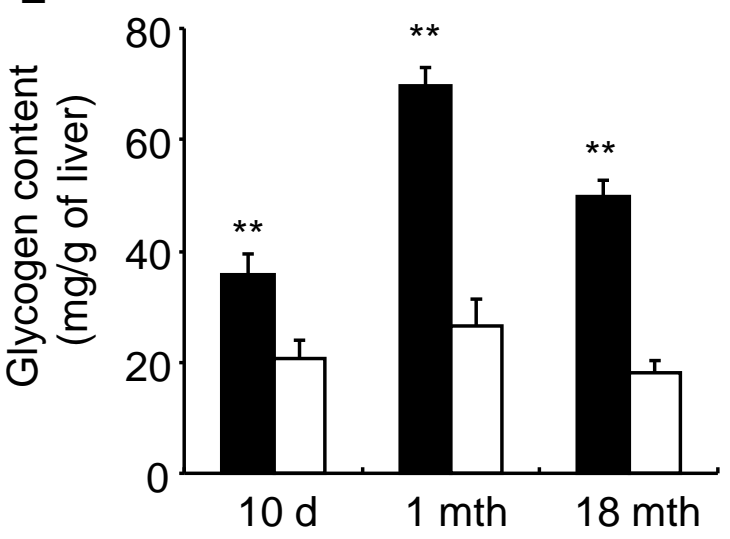

$\mathbf{F}$

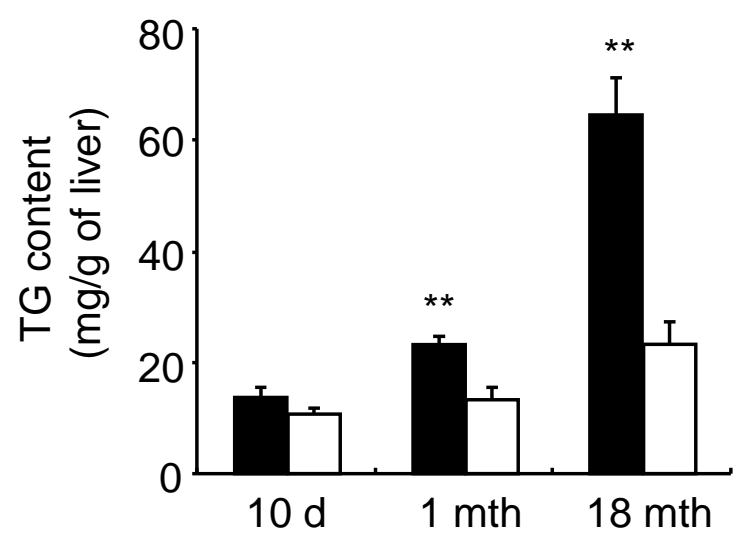


Control L-G6pc ${ }^{-1-}$
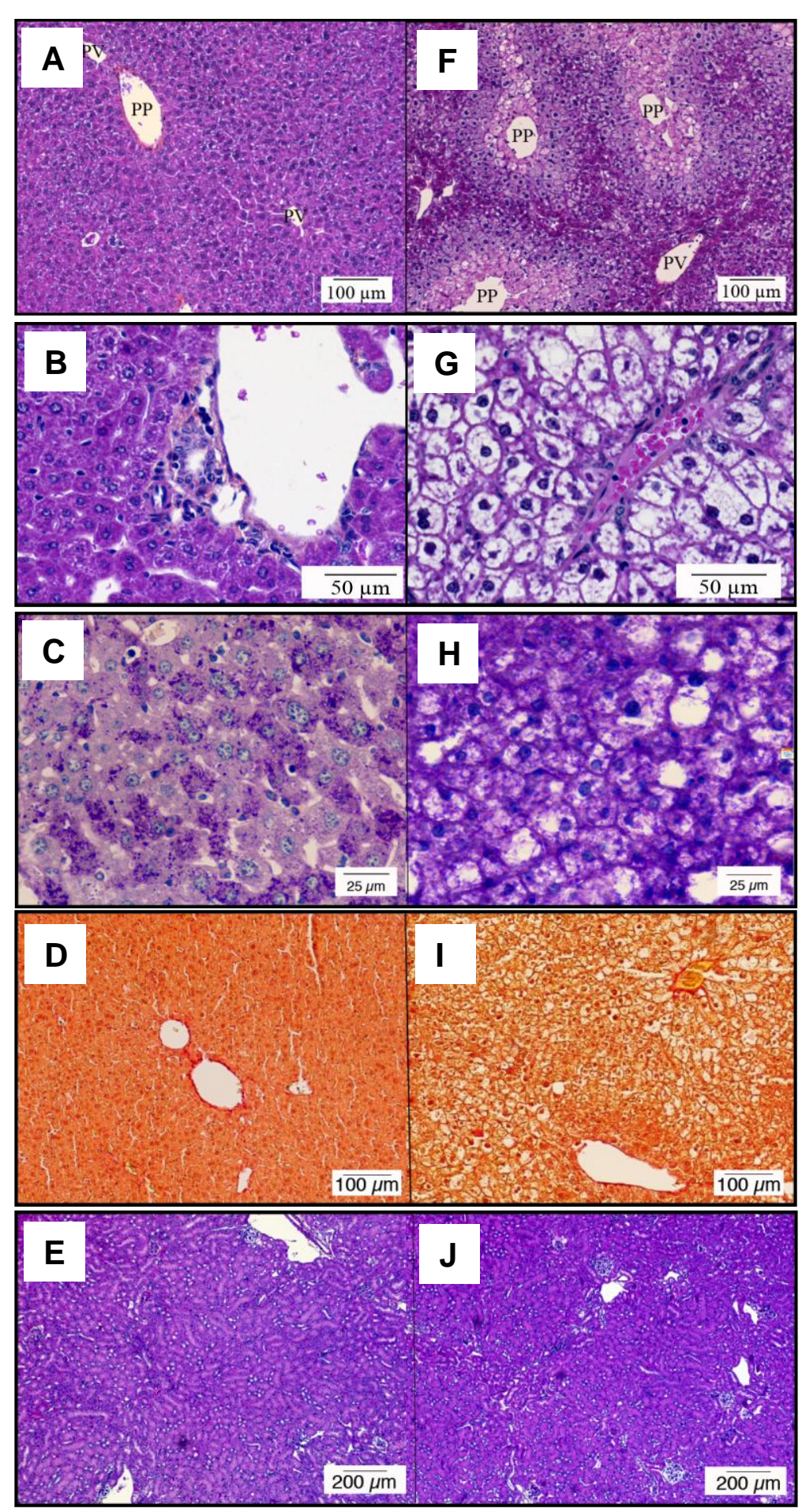

Mutel et al., Figure 5

Figure 5

Figure 5 .$$
\text { . }
$$ 

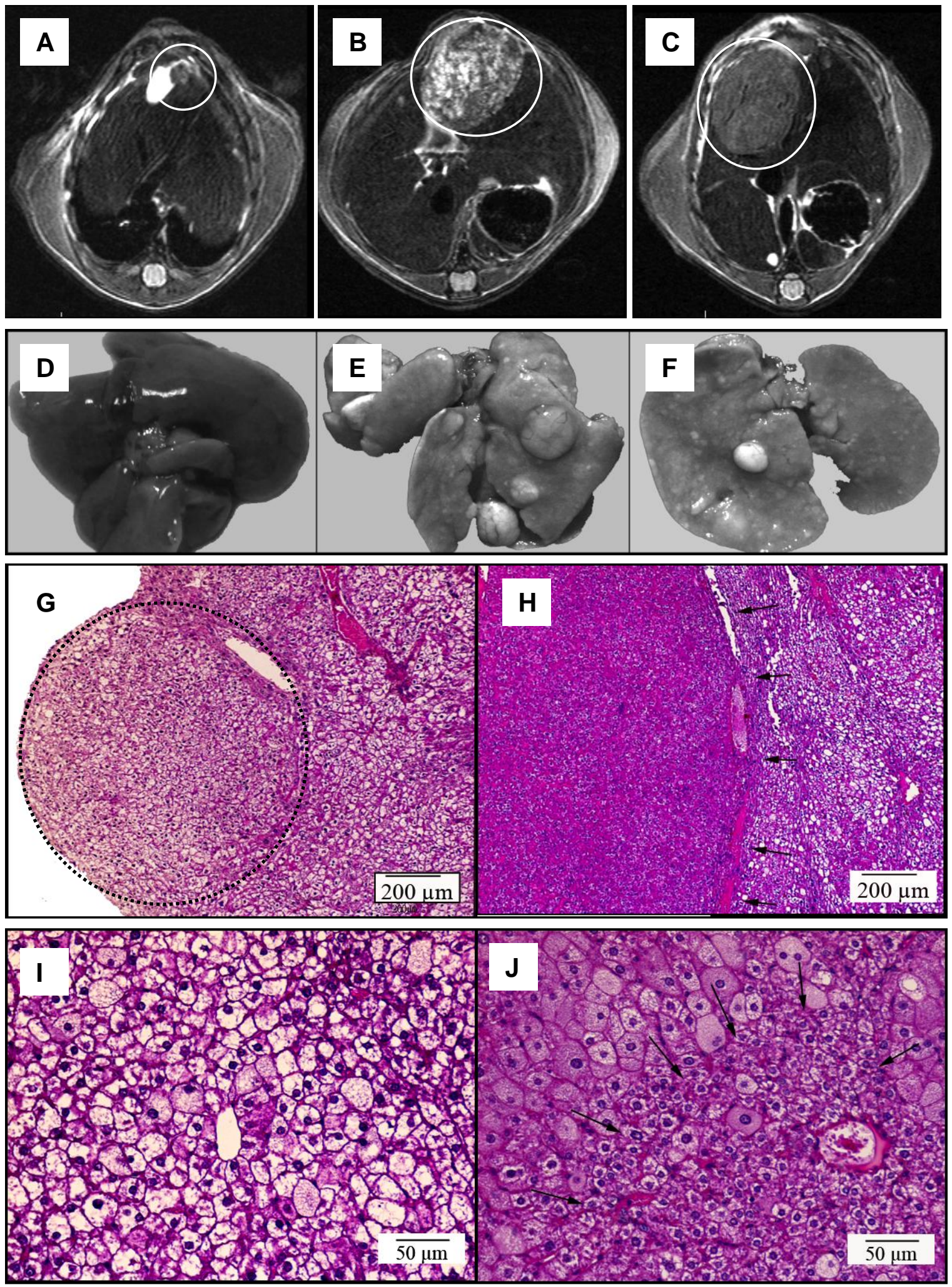

Mutel et al., Figure 6 